\title{
Re-knitting Diversity and National Unity: A Contemplation of Pancasila in Practice
}

\author{
Febri Fajar Pratama ${ }^{1)}$, Ai Kusmiati Asyiah ${ }^{2)}$, Deni Chandra ${ }^{3)}$ \\ Tasikmalaya University of Struggle Jl. Map No. 177, Kahuripan, Kec. Tawang, Tasikmalaya City, \\ Indonesia ${ }^{1,2,3)}$ \\ febripratama@unper.ac.id
}

\begin{abstract}
Pancasila is a guideline in the life of the nation and state, the values contained in it become a necessity that is inherent in every Indonesian citizen. However, Pancasila is inseparable from challenges and threats that come both from outside and from within. The dynamics of the problems that occur are not only about politics and ideology, but are mostly dominated by problems of unity and diversity, which include religious sentiment, primordialism, identity politics, separatism, and tolerance between people. Especially at this time, during the reform era, the challenges and threats were getting real and started sticking again. This study aims to examine deeply about these problems from the point of view of educators, especially the Pancasila education lecturers. The approach used is qualitative with descriptive analytical methods through interviews and literature studies. The results obtained are the need to ground the values of Pancasila, reduce group egoism, revitalize Pancasila education, reconstruct an egalitarian political system, and understand the original intent of Pancasila. So it can be concluded that diversity and unity must be endeavored together, as well as the need for synergy between the government, and all elements of society in general to create an Indonesia that puts forward the principles of national unity.
\end{abstract}

Keywords: Diversity; Unity; Pancasila

\begin{abstract}
Abstrak. Pancasila merupakan pedoman dalam kehidupan berbangsa dan bernegara, nilai-nilai yang terkandung di dalamnya menjadi sebuah keniscayaan yang melekat pada diri setiap warga negara Indonesia. Namun, Pancasila tidaklah lepas dari tantangan dan ancaman yang datang baik dari luar maupun dari dalam. Dinamika permasalahan yang terjadi tidak hanya soal politik maupun ideologi, tetapi sebagian besar didominasi oleh masalah persatuan dan juga kebhinekaan yang meliputi sentimen agama, primordialisme, politik identitas, separatisme, dan toleransi antar sesama. Terlebih saat ini, pada masa reformasi, tantangan dan ancaman itu semakin nyata dan mulai mencuat kembali. Penelitian ini bertujuan untuk mengkaji secara dalam mengenai permasalahan tersebut dari sudut pandang para pendidik, khususnya dosen Pendidikan Pancasila. Adapun pendekatan yang digunakan yaitu kualitatif dengan metode deskriptif analitis melalui wawancara dan studi literatur. Hasil yang didapat yaitu perlu adanya pembumian nilai-nilai Pancasila, menurunkan egoisme kelompok, revitalisasi Pendidikan Pancasila, merekonstruksi sistem politik yang egaliter, dan pemahaman tentang original intent dari Pancasila. Sehingga dapat disimpulkan bahwa kebhinekaan dan persatuan harus diusahakan bersama, serta perlunya sinergitas antara pemerintah dan seluruh elemen masyarakat pada umumnya untuk mewujudkan Indonesia yang mengetengahkan prinsip-prinsip kesatuan bangsa.
\end{abstract}

Kata Kunci: Kebhinekaan; Persatuan; Pancasila 


\section{INTRODUCTION}

"The recent events, brothers and sisters, have clearly proven that if it were not on the basis of Pancasila we were divided, it is clear that only Pancasila can continue to unite our country, can still save our country. Therefore, I hope that later when I have elaborated on Pancasila, you will always remember the background that I gave to you tonight, that we need unity and that Pancasila is except for one weltanschauung, which is a unifying tool rather than the diverse Indonesian people. this color." (Excerpts from Bung Karno's Speech in the Book of Tjamkan Pantjasila, 1964:65)

The quote from Bung Karno's speech above can illustrate how Pancasila is not only positioned as a state foundation, but also as a unifying tool that can protect and at the same time become a way out of all kinds of national problems. It is not surprising why Bung Karno thought that way, because philosophically, Pancasila was built on the foundation of unity and common struggle. We certainly still remember the feeling of Pancasila principles, one of which is ekasila, namely mutual cooperation in the BPUPK forum which was held from April 29 to June 1, 1945. Why did Bung Karno choose gotong royong? Because gotong royong is the Indonesian nation itself. Gotong royong has become the pulse that animates the values of togetherness, and has even been a feature of Indonesian society since the first. Gotong royong is a dynamic ideology, more than a sense of kinship,
Diversity that displays the context of differences, then the unity that displays the context of national unity is something that continues to be echoed to realize Indonesia as a plenary state. However, challenges and problems even after Pancasila was ratified as the basis of the state on August 18, 1945 did not stop attacking a country that was arguably still very young at that time. We take examples of major tragedies such as the PKI rebellion in Madiun led by Muso in 1948, the RMS (Republic of South Maluku) rebellion in 1950, the APRA (Ratu Adil War Force) rebellion in 1950, the DI/TII rebellion in Aceh in 1953, the Permesta rebellion ( The People's Struggle of the Universe) in 1957, then the G30S/PKI movement in 1965 which caused 7 highranking officers to die as a result of the action of the PKI propaganda and became the beginning of the collapse of the old order regime.

Not only in there, the New Order era was also inseparable from problems such as social unrest, separatism, democracy that was considered "dead", primordialism, development gaps between the center and the regions, and so on. In fact, this condition seemed to continue to be maintained until the end of the New Order era in 1998, which began with a social reform movement by the public and students who demanded Suharto to resign from his position. Demands were met, reforms rolled out, a new government was started, and the problems that arose were also increasingly 
complex. Even though the problem is not as severe as when the Republic of Indonesia was founded, we need to be careful too, because like a parasite, the current problems will hinder Indonesia's progress in the future.

Bung Karno once said that independence is not a goal, but a tool that functions as a "Golden Bridge" to achieve a just and prosperous society (Kasenda, 2014). Based on this, we can interpret that the real challenge of the nation's struggle is when the nation has obtained its independence, then what are the next steps that can be taken to fill that independence? Of course, by maintaining and maintaining what we have built and fought for together. However, it is not as easy as turning the palm of the hand. Everything has consequences, even after more than 70 years of Indonesia's independence. Suryadi \& Mahdi (2012) said that if Indonesia currently has lost its social capital, the spirit of unity and integrity has faded. The Indonesian people seem to find it difficult to cooperate in describing the nation's problems as a result of the changes and developments of the times that are currently happening. Perhaps this is also due to the absence of a "common enemy" that is the target of resistance. So we feel no obligation to do more. This is also exacerbated by the limited knowledge of the community about the importance of Pancasila as a guide to the life of the nation and state. Pancasila seems to only be used as a meaningless symbolism that we only hear at the flag ceremony.
Divinity values lack tolerance, human values that display violence, values of unity that uphold division, democratic values and deliberation that are crushed by egoism, and values of social justice that are full of inequality.

The data on paper actually shows that our national identity is at a percentage of $66.4 \%$ for the last three years (2017 - 2019), support for Pancasila and the 1945 Constitution has also strengthened among the Muslim population, namely $86.5 \%$, but those who consider Pancasila and the 1945 Constitution is not suitable because it is contrary to Islamic teachings also slightly increased, although not significant at $4.0 \%$. Meanwhile, the trend of issues of political intolerance and religious intolerance actually stagnates and also increases, such as the problem of building houses of worship, from 2017 (48\%) up to $53 \%$ in 2019 , and religious events whose percentage tends to stagnate at $36 \%$. Then for non-Muslim communities, the level of tolerance is still very high, but there is a decrease from 2018 (LSI, 2019).

When referring to quantitative research surveysBased on the above, it can be seen that the percentage indicates that there is a strengthening in terms of national identity, and the support of the majority Muslim community towards Pancasila and the 1945 Constitution. But in the field and what we see in the mass media, it seems the opposite is true. Borrowing a legal term, Pancasila is basically what we 
aspire to as a nation, but basically, the practice is not appropriate. The facts in the application and implementation of Pancasila values have not been fully realized.

Based on this, the authors are interested in studying the concept of diversity and unity in the context of Pancasila contemplatively to re-knit the unity and integrity of the Indonesian nation in the current era of globalization and modernization with all kinds of challenges. The formulation of the problem from this research are: (1) Why is diversity and unity important for the people of Indonesia?, (2) How is the practice of Pancasila values in today's society?, (3) How is the long journey of the Indonesian nation in building the concept of diversity and diversity? unity?, (4) What efforts can be made to maintain the diversity and unity of Indonesia?

\section{RESEARCH METHODS}

This research uses descriptive analytical method with a qualitative approach. This method was chosen because it adapts to the needs of researchers to interpret the data descriptively through in-depth interpretation. According to Sugiyono (2020) qualitative research emphasizes more on extracting meaning than generalization. While Muchtar (2015) defines qualitative research as something related to aspects of quality, value or meaning contained in empirical reality facts that can only be explained through language or words, so that the data presented is not in the form of numbers, scores or values analyzed through statistics,

Collecting data in this study using interview techniques and literature study. The interviews were conducted with purposively selected Pancasila Education lecturers with different backgrounds (from campus and region). Due to time considerations and difficulties in conducting interviews, the researchers only chose 6 informants. While the literature used as a reference source is in the form of books and journal articles.

\section{DISCUSSION}

It should be understood together that Indonesia is a country consisting of various tribes, ethnicities, religions, and cultures. All of this makes Indonesia a country with sufficient diversityhigh. In other terms, diversity is called the pluralistic concept. In the world, we can at least distinguish the structure of society into two categories, namely relatively homogeneous state societies and heterogeneous state societies. In this order, the pluralistic categorization is based on what is classified by Van Gunsteren (in Wahab \& Sapriya, 2011) into differences in race, class, gender, nationality, religion, profession, and political party. According to Wahab \& Sapriya (2011) Pluralism is a necessity in itself, but on the other hand it is something that needs to be anticipated because it is prone to social conflict. This is due to the possibility of intersect as a result of existing differences. 
Indonesia can be said to be a country that is blessed with a variety of geographical and demographic factors. Sukarno always boasted of this diversity through his speeches abroad so that other nations could recognize Indonesia as a great nation, a nation with diverse ethnicities and cultures, and a sovereign nation. During his visits to various countries, Sukarno emphasized "I want to tell foreigners and give a first glimpse of my beloved country which is green, like a string of emeralds of the equator". This is what Sukarno tried to build through Pancasila in the conception of Bhinneka Tunggal Ika (Adams, 2018).

In general, we know that Bhinneka Tunggal Ika is the motto of the Indonesian state, which is symbolically written on the ribbon held by the Garuda Bird. Bhinneka Tunggal Ika itself means "unity in diversity". Described by Pursika (2009), that "Bhinneka Tunggal Ika" is quoted from one of the stanzas in Mpu Tantular's Suta Soma Book in the 14th century during the Majapahit kingdom. The stanza contains about the differences between Buddhism and Hinduism, but they can be recognized because of their singular truth. As written in the original script:

Rwāneka dhātu winuwus Buddha Wiswa,

Bhinnêki rakwa ring apan hit the

Parwanosen,

Mangka ng Jinatwa against iwatatwa single, Bhinnêka Tunggal ika tan hana dharma mangrwa.
Meaning:

It is said that Buddha and Shiva are two different substances.

They are indeed different, but how can they be recognized?

For the truth of Jina (Buddha) and Shiva is one.

Pursika also provides an analysis of the meaning of "Bhinneka Tunggal Ika" conceptually and etymologically. Initially Bhinneka Tunggal Ika was a symbol of religious tolerance, namely Buddhism and Hinduism who lived in harmony and peace. But gradually the conception changed and developed more broadly to show the spirit of unity in diversity which includes differences in ethnicity, religion, race, and between groups. Meanwhile, in etymological meaning, Pursika provides the following analysis: "The motto 'Bhinneka Tunggal Ika' which comes from Sanskrit consists of the words 'Bhinneka', 'Single', and 'Ika'. The word 'Bhinneka' comes from the words 'Bhinna' and 'Ika'. 'Bhinna' means different and "Ika" means that. So, the word 'Bhinneka' means 'the different'. Another analysis shows that the word 'bhinneka' consists of the word 'bhinn-a-eka'. The element 'a' means no, and 'eka' means one. So, the word 'bhinneka' can also mean 'the one who is not One'. While the word 'single' means one, and 'Ika' means that. Based on this analysis, it can be concluded that the motto 'Bhinneka Tunggal Ika' means 'different in one' or 'diverse yet one'." 
Latif (2019) describes the concept of diversity and unity very comprehensively. It begins with a narration from Bung Karno's speech on June 1, 1945 about how to establish an independent Indonesia that is not only for one person, one group, or one group, but for everyone. So the Indonesian nationality is a unanimous nationality, namely the Indonesian nationality which together form the basis of one nationale staat. Then Latif emphasizes universal humanitarian commitment as an important factor in its relationship to be able to glue pluralism. This means that unity will not be realized if the actualization of human values is not carried out in tandem, because basically the ethical values contained in it such as the attitude of brotherhood, equality, peace.

In addition, the conception of diversity and unity can be drawn backwards based on a historical perspective, namely the beginning of the formation of the Indonesian mainland in prehistoric times, until it was transformed into its current form, where the Indonesian archipelago was formed as a result of the increasing volume of sea water that occurred continuously. Gradually until the end of the Glacial Wurm (ice age). Previously, the land that formed Indonesia was a combination of two landmasses, namely the Asian continent and the Australian continent. The extension from the Asian continent is called "Sundaland" and the extension from the Australian continent is called "Sahulland". This is what then creates biodiversity and demographics, because in the West it is influenced by mainland Asia, while in the East it is influenced by mainland Australia which is separated by a trough known as the Wallacea line. However, the biodiversity on the mainland of Wallacea is different from the main land, because it was isolated which made the flora and fauna on this land different / endemic (typical). At that time, Indonesia was still referred to as the Archipelago, where the beginning of human civilization the archipelago was suspected to consist of several types of races classified into the Southern Mongoloid race which included Southeast Asia, Indonesia, Malaya and the Philippines (Indonesia itself generally consists of the Austro -Melanesoid with black skin and Austro-Mongoloid race with olive skin) As for differences in skin color, body shape, and face, it is inseparable from geographical factors, environmental conditions, weather climate, the process of natural selection, and the existence of interbreeding between races with one another. After millions of years passed, humans began to develop and build a modern civilization with its culture and social system.

The history of the archipelago started from the beginning of the first century $A D$ with the royal government system, the opening of trade routes, the entry of other countries' influences, cultural acculturation, until the Dutch colonialism period. Even so, the seeds of nationalism can be studied since the days of the kingdom. Latif (2019) explains how the 
archipelago, which consisted of archipelagic communities at that time, especially the rulers in the archipelago was accustomed to absorbing new elements to be mixed into old elements so as to create what Latif called a cross-cultural pollination cauldron. The beginning of the synthesis element which then triggered one of the doctrines of "Civil Religion" in the Majapahit era which was internalized in Mpu Tantular's discourse in the Suta Soma book, "Bhinneka Tunggal Ika tan Hana Dharma Mangrwa", different but one.

This fact inspired Bung Karno to elaborate the concept of national unity. Through his synthesis of the opinions of Renan and Otto Bauer, Bung Karno (2019) revealed that to achieve a national unity, there is no need for language unity, skin color unity, or religious unity. Although each has differences, as long as they are a group of people who have experienced the same fate, whether for decades or even hundreds of years, what is called a unity of character will grow, and it is this unity of character that determines the nature of the nation. However, Sukarno saw Renan and Otto Bauer's understanding of the nation as incomplete when referring to the condition of the Indonesian people, so an additional aspect was needed, namely the unity of place. According to Bung Karno, a nation is a large group of people.

Why is this issue of diversity and unity so important? Because Indonesia is not a country consisting of a homogeneous society, but a plural society with various differences of each. It is impossible for Indonesia to be independent if the spirit of struggle is not manifested in the past, and it is impossible for these differences to be melted away if not for the spirit of unity. This seems to be the antithesis of what was once expressed by Colijn (1928) in his book entitled "Koloniale vraagstukken van heden en morgen" that the term Indonesia is only a concept of unity formed without substance, the term should only apply to geographical concepts, even if imposed on a political concept then the formulation is not good. He considered the Dutch East Indies government to be the real unifier, if the Dutch authorities were overthrown by the so-called anti-Western imperialism movement then it would not have much effect, because it would be replaced by other authorities, so that the concept of Indonesian unity was only a mirage. Colijn also described how the movement of the Indonesian people at that time was unyielding to realize an independent Indonesia, even though according to him it was only a utopia. He also doubts the youth groups who foster the spirit of Indonesia by calling it something "artificial". In the end, what Colijn said was not proven. 17 years later, after the Youth Pledge was proclaimed in 1928, Indonesia gained its independence. because it will be replaced by other authorities, so the concept of Indonesian unity is only a mirage. Colijn also described how the movement of the 
Indonesian people at that time was unyielding to realize an independent Indonesia, even though according to him it was only a utopia. He also doubts the youth groups who foster the spirit of Indonesia by calling it something "artificial". In the end, what Colijn said was not proven. 17 years later, after the Youth Pledge was proclaimed in 1928, Indonesia gained its independence. because it will be replaced by other authorities, so the concept of Indonesian unity is only a mirage. Colijn also described how the movement of the Indonesian people at that time was unyielding to realize an independent Indonesia, even though according to him it was only a utopia. He also doubts the youth groups who foster the spirit of Indonesia by calling it something "artificial". In the end, what Colijn said was not proven. 17 years later, after the Youth Pledge was proclaimed in 1928, Indonesia gained its independence. although he thought it was just a utopia. He also doubts the youth groups who foster the spirit of Indonesia by calling it something "artificial". In the end, what Colijn said was not proven. 17 years later, after the Youth Pledge was proclaimed in 1928, Indonesia gained its independence. although he thought it was just a utopia. $\mathrm{He}$ also doubts the youth groups who foster the spirit of Indonesia by calling it something "artificial". In the end, what Colijn said was not proven. 17 years later, after the Youth Pledge was proclaimed in 1928, Indonesia gained its independence.
Indonesia todayexperienced various challenges, especially those related to the implementation of the values of Pancasila which emphasizes tolerance for differences and unity. Conflicts involving elements of SARA (Ethnicity, Religion, Race, and InterGroup) are very vulnerable to occur, even the level of offence and disintegration feels more intense, causing prolonged horizontal conflicts (Lestari, 2015). Suparlan (2014) reveals that there are at least three things that have the potential to disintegrate the Indonesian nation, namely: (1) the Bhinneka Tunggal Ika style which focuses on ethnic and ethnic diversity, not cultural diversity. So that ethnic diversity should be the product of that cultural diversity; (2) A semi-militaristic, corrupt, national system and lack of justice, causing people to prefer to take refuge within the scope of ethnicity; (3) An undemocratic society. The concept of Pancasila democracy has only become an appendage or lip-service, especially during the reign of President Suharto. However, even though the New Order regime has ended, this phenomenon does not end just like that, because it has become a real actual culture in Indonesian people's lives to be used for social, economic, and political gain.

Suparlan also proposed the importance of changing the paradigm of emphasizing ethnic diversity in Bhinneka Tunggal Ika, into cultural diversity, so that the substance changes from a pluralistic society to a multicultural (culturally diverse) society. 
Differences that are more prominent than common interests in achieving one national and state goal will ultimately weaken the joints of unity. Unity basically does not merge all cultures, all differences become one, or leads to monoculturalism which does not accommodate minority rights. Unity of Indonesia should lead to multiculturalism which emphasizes the equality of cultural differences. A multiculturalist society will position itself not only as an individual from an ethnic group.

Currently, the issue ofintegration and unity seem to be "thickened" through regional, tribal, ethnic, and religious sentiments. One of these moments can be seen in the 2017 DKI Jakarta Pilkada. At that time, Jakarta, which was considered a miniature of Indonesia because of its position as the capital city, became the center of public attention. The euphoria of the Pilkada is not only enjoyed by the citizens of DKI Jakarta. This of course makes us regress to the back of the new order era with its Jakarta centricity which is actually less relevant in the context of contemporary politics (Haboddin, 2012). Not many people realize that the implementation process is thick with the nuances of identity politics. Basuki Tjahaya Purnama (Ahok), who was one of the candidates for governor at that time, was even attacked by issues of ethnic and religious racism. This then led to the polarization of religious fundamental groups with nationalist groups. Whereas identity politics has actually been going on for a long time, such as the growing assumption about the position of the President which is dominated by Javanese ethnicity, or discrimination against the political rights of minority groups, and so on. But the people at that time did not really understand the identity politics. After experts, political observers and the media continued to discuss the phenomenon of identity politics in the DKI Pilkada, the public finally began to realize the dangers of this condition if it continued to be carried out in "overdose" doses. According to Sari (2016) identity politics is deliberately built by local elites to perpetuate power or gain power to establish their influence in the local political sphere by using identity backgrounds.

The problems described above are only a few facts that occur in the field related to how the actual implementation of Pancasila values, especially regarding diversity and unity has not been optimally carried out. There are still many other problems that we must identify and find solutions together. So what can we do? Based on the results of the study (through interviews conducted), obtained alternative problem solving in the form of:

1. The grounding of Pancasila values. This is very important to do because the challenges ahead are increasingly complex along with the times that occur, so that Pancasila should not lose its appeal and the people's lifestyle is far from the values of Pancasila. This is in line with what was conveyed by 
Wardani (2019) regarding the internalization of values. Through his research, it is said that the internalization process can help a person to define his own values and also when he is in his society which is created in the form of a series of norms and practices.

2. Mutual respect (tolerance), prioritizing tolerance, and reducing group egoism. The maturation of the nation's self must be realized immediately, because without it, small things can become a trigger for disintegration. We must be aware that the Indonesian people are not a nation consisting of one group or class, it will be very difficult to unite differences if they still consider differences as a barrier in achieving the goals of the state, it will be very difficult if the goals are only based on the goals of each group. This statement is in line with what was conveyed by Kadarmanto (2018) that the unity of Indonesia is a shared commitment to achieve one goal and hope, namely achieving wholeness and harmony that supports the prosperity and welfare of the community as a whole.

3. Revitalization of Pancasila Education. In order to change the mindset and behavior of the community massively, of course, a good education system is needed. So education is one of the main indicators of the nation's progress. Pancasila education which was originally indoctrination and cognition, should now be considered for revitalization, given sufficient space to develop in a more inclusive and comprehensive direction. Pancasila education must also include the formation of character, personality, and understanding of multiculturalism. This is in line with what is expressed in the writings of Suparlan and also the Pharisees; According to Farisi (2014) the concept of Diversity and Unity of course cannot only be conveyed in the form of theories and pedagogical perspectives without referring to the goals of the state, so harmony is needed. So that later students as citizens are able to live in a pluralistic society and coexist peacefully and can contribute to national integration.

4. Reconstructing an egalitarian political system. Of course, in ensuring justice and equal rights among citizens, there needs to be an egalitarian political system, prioritizing tolerance, open-mindedness, no discrimination, no haphazard fulfillment of rights that benefit certain groups, no tyranny of power, and no majority. over power, and there should be no coercion of will. This statement is in line with what was conveyed by Sadjim, Muhadjir, and Sudarsono (2016) that unhealthy politics will lead to social conflicts, especially power politics wrapped in personal interests by involving SARA (Suku, Agama, Ras, \& Antar Golongan) issues. As 
a result of this, the noble values of local wisdom began to be disturbed, such as the value of unity and integrity, tolerance, trust between community members, and the spirit of togetherness. In addition, the impact of this social conflict can lead to suspicion, group egoism, and increase emotional feelings.

5. Understanding the original intent of Pancasila. This means that we must understand how Pancasila was formulated, how Pancasila was proposed, how Pancasila was formed, and how Pancasila was ratified from the point of view of the Pancasila thinkers themselves. This deepening will have an impact on our understanding and view of the original meaning and purpose of Pancasila. Not based on limited personal interpretation. Because many interpret Pancasila as they like, and come to narrow conclusions, such as suitable and not suitable or contrary to the values they hold. As stated by Widisuseno (2014) that the philosophical study of Pancasila as the ideology and basis of the state is a critical effort to open awareness of the historical memory of the Indonesian nation,

\section{CONCLUSION}

Diversity and unity are the main concerns to prevent resistance to the application of Pancasila values which are considered no longer in accordance with the progress and development of the times. Gradually, people began to be influenced and led to the understanding and imperialism of the new style of thought. Most of the nation's problems are always driven by the interests of certain groups or groups who want to divide the Indonesian nation. Therefore, synergy between the government and all components of society is needed to maintain diversity in unity in accordance with the values of Pancasila. Bhinneka Tunggal Ika (Unity in Diversity) should be the motto of the nation's glue which is not interpreted in the context of ethnic differences, but rather cultural differences in which there are differences in ethnic, ethnic, and cultural elements. culture, religion. The Indonesian people should also maintain harmony to realize the harmony of diversity which leads to national unity.

\section{REFERENCES}

[1] Adams, Cindy. (2018). Bung Karno Penyambung Lidah Rakyat. Yogyakarta: PT. Media Pressindo

[2] Colijn, H. (1928). Koloniale vraagstukken van heden en morgen. NV Dagblad en Drukkerij de Standaard.

[3] El Mahdi, H., \& Suryadi, S. (2012). Menemukan Kembali Kapital Sosial Bangsa Indonesia. Interaktif, 1(1).

[4] Farisi, M. I. (2014). Bhinneka Tunggal Ika [Unity in Diversity]: From Dynastic Policy to Classroom Practice. JSSE-Journal of Social Science Education.

[5] Haboddin, M. (2012). Menguatnya Politik Identitas di Ranah Lokal. Jurnal Studi Pemerintahan, 3(1). 
[6] Kadarmanto, M. (2018). Merajut Kesatuan Dalam Keberagaman Di Indonesia: Tinjauan Teologis Untuk Mengamalkan Sila "Persatuan Indonesia". Manna Rafflesia, 4(2), 92-109.

[7] Kasenda, Peter. (2014). Sukarno Muda Biografi Pemikiran 1926 - 1933. Depok: Komunitas Bambu.

[8] Latif, Yudi. (2019). Negara Paripurna. Jakarta: PT Gramedia Pustaka Utama

[9] Lestari, G. (2016). Bhinnekha Tunggal Ika: Khasanah Multikultural Indonesia Di Tengah Kehidupan SARA. Jurnal Ilmiah Pendidikan Pancasila dan Kewarganegaraan, 28(1).

[10] LSI. (2019). Tantangan Intoleransi dan Kebebasan Sipil Serta Modal Kerja pada Periode Kedua Pemerintahan Joko Widodo: Temuan Survei Nasional 8-17 September $2019 . \quad$ [tersedia online] http://www.lsi.or.id/riset/447/rilis-survei-lsi03-november-2019. [diakses tanggal 21 Desember 2020]

[11] Muchtar, Suwarma Al. (2015). Dasar Penelitian Kualitatif. Bandung: Gelar Pustaka Mandiri

[12] Pursika, I. N. (2009). Kajian Analitik Terhadap Semboyan" Bhinneka Tunggal Ika". Jurnal Pendidikan dan Pengajaran, 42(1 Apr).

[13] Sadjim, U. M., Muhadjir, N., \& Sudarsono, F. X. (2016). Revitalisasi Nilai-Nilai Bhinneka Tunggal Ika dan Kearifan Lokal berbasis Learning Society Pascakonflik Sosial di Ternate. Jurnal Pembangunan Pendidikan: Fondasi dan Aplikasi, 4(1), 79-91.

[14] Sari, E. (2016). Kebangkitan Politik Identitas Islam Pada Arena Pemilihan Gubernur Jakarta. KRITIS: Jurnal Ilmu Sosial dan Ilmu Politik Universitas Hasanuddin, 1(1), 145156.

[15] Sugiyono. (2020). Metode Penelitian Kualitatif. Bandung: Alfabeta

[16] Sukarno. (1964). Tjamkan Pantja Sila Pantja Sila Dasar Falsafah Negara. Jakarta: Departemen Penerangan RI
[17] Sukarno. (2019). Filsafat Pancasila menurut Bung Karno. Yogyakarta: Media Pressindo

[18] Suparlan, P. (2014). Bhinneka Tunggal Ika: Keanekaragaman Sukubangsa atau Kebudayaan?. Antropologi Indonesia.

[19] Wahab, Abdul Azis \& Sapriya. (2011). Teori dan Landasan Pendidikan Kewarganegaraan. Bandung: Alfabeta

[20] Wardani, W. (2019). Internalisasi Nilai dan Konsep Sosialisasi Budaya dalam Menjunjung Sikap Persatuan Masyarakat Desa Pancasila. NUSANTARA: Jurnal Ilmu Pengetahuan Sosial, 6(2), 164-174.

[21] Widisuseno, I. (2014). Azas Filosofis Pancasila sebagai Ideologi dan Dasar Negara. HUMANIKA, 20(2), 62-66. 